\section{INSURTECH: KÖRKÉP ÉS TRENDEK}

Sallai Linda (a CIG Pannónia Biztositói innovációsés digitalizációs igazgatója, emellett a FintechFlow nevü fintech témával foglalkozó angol nyelvü podcast alkotója, , , linda.sallai@gmail.com

\section{ÖSSZEFOGLALÓ}

Cikkem célja, hogy áttekintést adjak arról, hogy az insurtech vállalatok hogyan formálták át iparágunkat az elmúlt években, és melyek azok a trendek, amik már most is jelen vannak, illetve általánossá válhatnak a következő években.

A biztosítási iparág átalakulása megkezdődött, és aki versenyben akar maradni, annak be kell szállnia ebbe a nemes küzdelembe. Ráadásul a következő évtizedben nem csak meglevő versenytársainkkal kell megmérkőznünk. Egy iparági szintü átalakulás gyakran jár azzal, hogy meglévő szereplők ki-, és új szereplők belépnek a piacra. A biztosításban is megfigyelhető az iparági határok elmosódása, illetve bizonyos technológiák térhódítása új szereplők piacra lépését teszi lehetővé. Így a technológiai óriások vagy autóipari vállalatok is versenytársainkká válnak.

Célom, hogy cikkemmel informáljam és inspiráljam olvasóimat, és lehetőség szerint segítsem a biztosítós kollégákat abban az átalakulásban, ami meglátásom szerint feltétlenül végbe fog menni az iparágban. A kérdés csak az, hogy a változások után kitől fognak a jövő ügyfelei biztosítást vásárolni. Ha azt szeretnénk, hogy tőlünk, komolyan át kell formálni működésünket - ez a változás elkerülhetetlen.

\section{SUMMARY}

The purpose of this article is to give you an overview of how insurtech companies have disrupted and transformed our industry in recent years, and what trends are already present and may become mainstream in the coming years.

The transformation of the insurance industry has begun, and anyone who wants to remain in competition must enter this noble battle. What's more, over the next decade we will not only have to compete with our competitors and the challengers. Change on an industry level often occurs by the exit of existing and the entry of new players. In insurance, too, the blurring of industry boundaries and the proliferation of certain technologies allow new entrants to enter the market, making technology giants or automotive companies our competitors.

My goal is to inform and inspire my readers with my article and, if possible, to assist insurance colleagues in the transformation that I believe will definitely take place in the industry. The only question is, after the changes took place, who will your future customers buy from. If we want them to buy from us, we need to seriously reshape how we do business and this change is inevitable.
Kulcsszavak: insurtech, digitális átállás, ügyfélélmény, nyilt innováció, ökoszisztéma Keywords: insurtech, digital transformation, customer experience, open innovation, ecosystem JEL: G22, O33

DOI: $10.18530 /$ BK.2019.4.98

http://dx.doi.org/10.18530/BK.2019.4.98

\section{Bevezetó}

Meggyőződésem, hogy a biztosítási iparág az elkövetkező 10 évben olyan jelentős változásokon megy majd keresztül, amilyet ez a szakma még nem tapasztalt. Úgy látom, ebben az átalakulásban a biztosítók nagyon sokat tudnak veszíteni, és nyertesekké csak akkor válhatnak, ha élen tudnak járni olyan területeken, amelyek számunkra egyelöre újak vagy teljesen idegenek (pl. big data, blockchain, szoftverrobotok (RPA=Robotic Process Automation), a dolgok internete (IOT) vagy a felhasználói élmény megtervezése (UX= User Experience)).

Ehhez azonban ki kell lépni a komfortzónánkból, ami egy alapvetően kockázatkerülő magatartással bíró szakmának önmagában nehézséget okoz. Meg kell találni, sőt toborozni kell minden szervezeten belül a változás nagyköveteit. Mert a sikeres digitális transzformáció legalább annyira kulturális és gondolkodásmódbeli változást követel, mint technológiai felkészültséget. A technológia rendelkezésre áll, de megfelelő gondolkodásmód és szervezeti kultúra nélkül nincs esély ennek átültetésére. Jelenleg innovációs és digitalizációs igazgatóként dolgozom a CIG Pannónia Életbiztosítónál. Azoknál a cégeknél, akik versenytársainkká válhatnak 10 éven belül, ilyen pozíció nem létezik. Mert ők digitálisan működnek minden szinten, és náluk az innovatív gondolkodásmód, szervezeti kultúra, módszerek alkalmazása is alapvető. Ez nagyon erős komparatív előny lesz számukra a jövő ügyfeleiért vívott verseny során. Ők azonban nem ismerik a biztosítási iparágat, sőt, erősen szabályozott környezetben sem mozognak otthonosan. Ez a mi előnyünk lehet. A múltunk, a tapasztalatunk szintén előnyt jelent számunkra, de ez komoly teherrel is jár. A mi működési modellünk nem a digitális világra épül. Nekünk is van IT-nk és szervezeti kultúránk, és egy alapvetően kockázatkerülő, következésképpen változásra kevéssé nyitott szemléletünk. A múltunk sem csak előnyöket hordoz tehát.

Cikkemet a változás nagyköveteinek ajánlom. Minél többen vagyunk, annál inkább tudunk hatást gyakorolni, és vezetni saját szervezetünket, és közvetetten az iparágat is az eredményes jövő irányába. Ahogy a FintechFlow podcast életre hívásával is ez volt a célom, most is azt remélem, hogy ez a cikk - ha kis mértékben is, de - hozzásegít minket ahhoz, hogy olyan módon az ügyfelet középpontba helyezve transzformáljuk át magunkat és az iparágunkat, hogy 10 év múlva is tőlünk, biztosítóktól, ne pedig a nagy technológiai cégektől vásároljanak biztosítást az ügyfelek. 


\section{Legyen a központban az ügyfél}

A változások legfőbb mozgatórugójának gondolom az ügyfél középpontba helyezését. Ez gyakorlatilag a teljes értékláncon keresztül meg kell, hogy jelenjen. Bár egyre több, de még mindig kevés jó példát látunk erre világszerte, pedig ez a változás nemcsak jól felfogott üzleti érdekünk (kellene, hogy legyen), de elkerülhetetlen is lesz. Ennek oka, hogy az ügyfeleink nem a biztosítási iparágban megszerzett tapasztalataikra építik az elvárásaikat. A jövő ügyfelei számára különösen nem a stabil, 100 éves, nagynevü biztosítók a megbízható szolgáltatók, hanem az Amazon Prime, ahol ténylegesen zökkenőmentes felhasználói élményben van részük. A Bain\&Company 2018-as kutatása szerint a millennium generáció 80 százaléka kész arra, hogy a Google-től, Amazontól, Facebooktól, illetve Apple-től vásároljon biztosítás. Ráadásul ezen új sztenderdek elvárását erősítik a változásra építő új biztosítók, akiknek bár piaci hatásuk egyelőre elenyésző, de azt már megmutatták, hogy a máshol megszokott ügyfélélmény ebben az iparágban is elérhető.

A ma és a közeljövő ügyfelét nem érdeklik a háttérben zajló folyamatok. Ő láthatatlan és zökkenőmentes vásárlói élményt akar. Azt várja, hogy tudjuk, mire van szüksége, kínáljuk fel neki, és tegyük rendkívül egyszerűvé megvásárlását és használatát.

Ha megvizsgáljuk, hogy a biztosításukkal kapcsolatban tipikusan mivel elégedetlenek az ügyfelek világszerte, akkor kicsit hihetetlennek is tünik, hogy ezek a problémák még mindig nincsenek orvosolva. Alapvetően két csoportba sorolhatók a változási igények, ahogy ez az 1. ábrán is olvasható: az ügyfeleink egyszerűbb és személyesebb megoldásokat várnak el.

1. ábra: Az ügyfelek számára fájó pontok (eredeti angol nyelvủ válaszok)

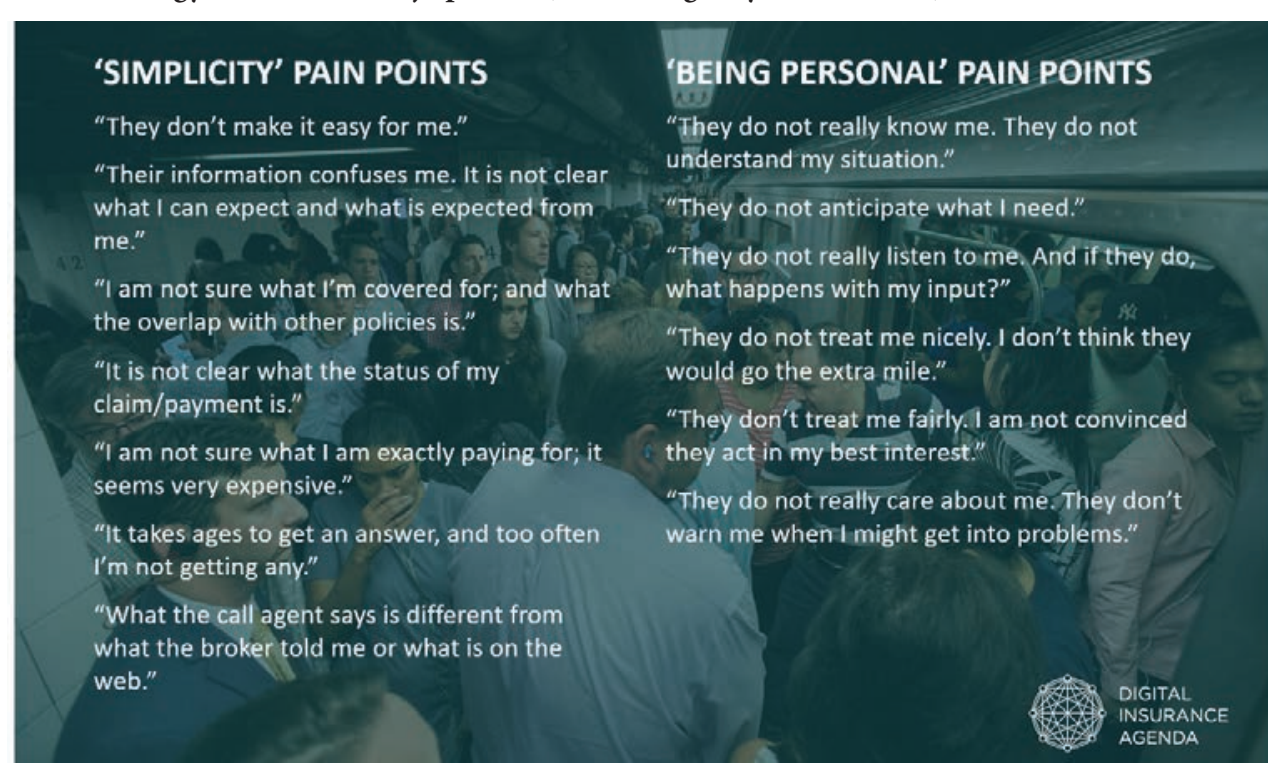

Forrás: https://www.digitalinsuranceagenda.com/thought-leadership/the-four-waves-of-insurtech/
Mindezek a problémák a mai technológiai eszközökkel orvosolhatók lennének. A biztosítók már elindultak ezen az úton, de az út még hosszú, ráadásul az iparágon kívüli versenytársak elött kellene az út végére érni.

A digitális transzformáció az ügyfelekről kell, hogy szóljon, hiszen ha nem elégítjük ki az igényeiket, nem adunk hatékony választ a problémáikra, el fognak hagyni.

Ennek fontossága talán még egyértelműbbé válik, ha megvizsgáljuk a másik oldalt, hogy milyen előnyöket jelenthet a pozitív ügyfélélmény.

Az ügyfeleink, amikor biztosítást vásárolnak tőlünk, nagyrészt azért fizetnek, mert bíznak abban az ígéretben, amit tőlünk kapnak. Ezt a bizalmat pedig a leginkább megfelelő ügyfélélménnyel tudjuk megszolgálni és építeni.

A mai (magyar) piacon ez egyértelmű versenyelőnnyé válhat annak a biztosítónak a számára, aki ezt magabiztosan tudja nyújtani, és mivel a digitális világban egyre inkább a kapott szolgáltatás minősége vezérli a vásárlói megfontolásokat, nagyon erős értékesítési érvvé válhat.

A magyar piaci statisztikák világosan mutatják, hogy a portfóliók minőségét, megmaradását javítani kellene, és az ügyfél-elégedettség ennek egyik legfőbb eszköze. (Különösen igaz ez az etikus életbiztosítási termékek esetében.) Mindez egybevág a szabályozói törekvésekkel.

Kutatások is alátámasztiák, hogy a kimagasló ügyfélélményt kapó ügyfelek nyitottabbak a keresztértékesítésre, kevésbé érzékenyek konkurensek ajánlataira, kiszolgálásuk kevesebbe kerül, és nagyobb valószínűséggel ajánlják a szolgáltatást a környezetükben.

Az innováció során a leglényegesebb pontnak tehát azt látom, hogyan leszünk képesek arra, hogy a technológia mai eszközeivel ezt az ügyfélélményt minél magasabb szinten tudjuk nyújtani.

Számos meghatározása van az innovációnak. Egy hozzám közel álló megfogalmazásban az innováció arról szól, hogy megértjük, a technológia hogyan változtatja meg az ügyfélviselkedést, majd kiaknázzuk ezt.

Cikkem további részében azt fogom megvizsgálni, hogy a mai technológiai fejlettség milyen változásokat indított el iparágunkban számos területen. Azokra az irányokra fókuszálok, amelyek már elterjedtebbek, és számos gyakorlati példa mutatja jelentőségüket. (Így például nem tárgyalom a blockchain technológia lehetséges hatásait.)

Az adat mint az innováció központi témája

Mai világunkban az adat az egyik legértékesebb erőforrás, ahogy mondani szokás, az adat az új olaj (lásd 2. ábra). Azonban az olajhoz hasonlóan, ha nem finomítják, és nem alakítják át, akkor használhatatlan. A biztosítási szektornak ezzel két problémája lehet:

1. Nincs adatunk

Jelenleg a biztosítási iparágban rendelkezésre álló adatmennyiség rendkívül kicsi. Igaz ez a pénzügyi szektor más szereplöihez (bankokhoz) képest, de még hangsúlyosabb a különbség például a technológiai óriásokkal összevetve (GAFA - Google, Amazon, Facebook, Apple).

2. Nem tudjuk megfelelően használni az adatokat

Érdekes ellentmondás, hogy bár aziparágunk hozzá van szokva adatok elemzéséhez és azok 
használatához a kockázatok felmérése és árazása során, egyelöre az látszik, hogy problémát jelent számunkra a rendelkezésre álló úffajta adatok kezelése és hasznosítása egyaránt.

\section{2. ábra: Az adat az új olaj (Data is the new oil)}

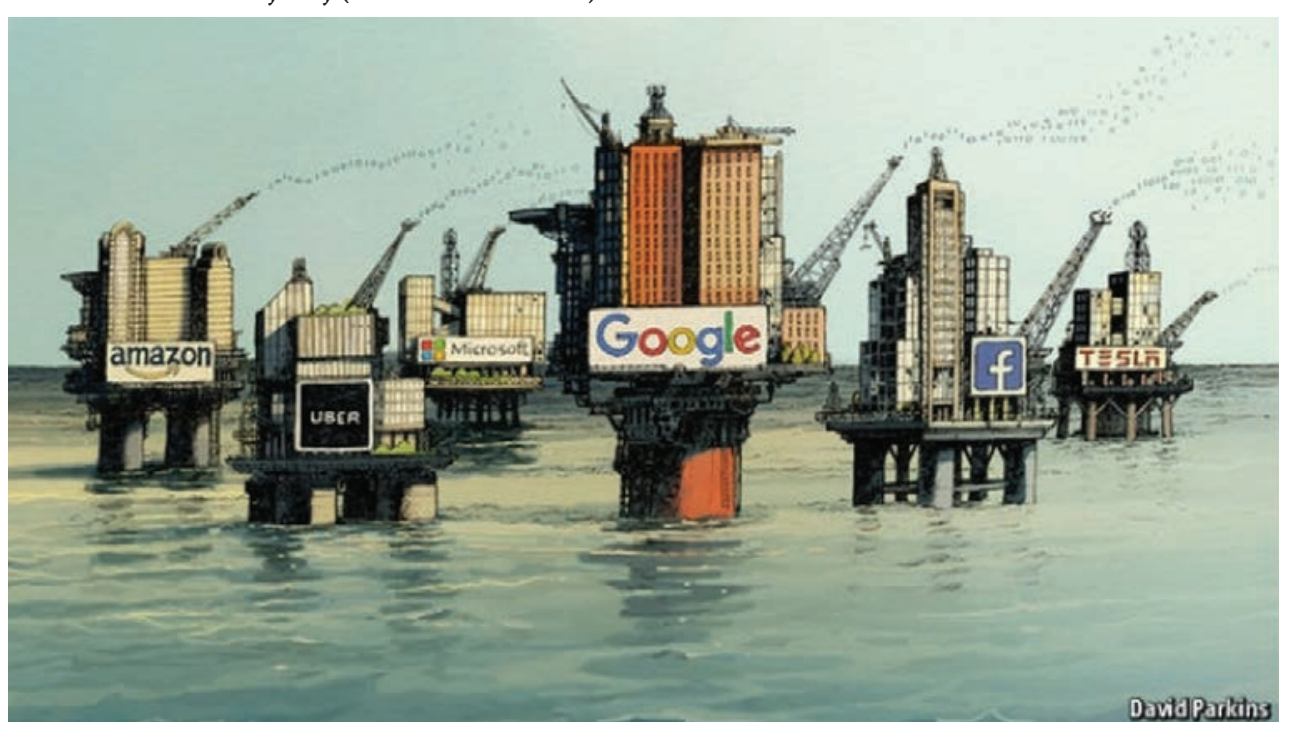

Forrás: https://www.economist.com/leaders/2017/05/06/the-worlds-most-valuable-resource-is-no-longeroil-but-dato

A következőkben azt nézzük meg, hogy az értéklánc mely területeire lesz komoly hatással ez az újfajta adatkörnyezet. Mindenhol igyekszem konkrét példát is hozni, egy-egy olyan insurtech vállalatot, amely az adott területet magas színvonalon képviseli.

\section{Díjkalkuláció, árazás}

A ma rendelkezésre álló adathalmaz a biztosítási kockázatok árazását teljesen új alapokra tudná helyezni. Az új technológiáknak, a gépi tanulásnak és a rendelkezésre álló adatoknak köszönhetően ma már sokkal pontosabban tudjuk/tudnánk felmérni a kockázatokat. Élet-, egészég- és vagyonbiztosítási területen egyaránt újfajta metrikák kialakulására kell számítani. A kockázatok pontosabb felmérése személyre szabottabb és igazságosabb, sőt, a bizonytalansági faktor csökkentésének köszönhetően általánosságban olcsóbb díjakhoz vezethet. Számos insurtech próbálja megreformálni ezt a területet, ilyen például az Amodo, akik viselkedési adatok (behavioral data) gyưjtésével és elemzésével alakítanak ki és áraznak termékeket, és kínálják ezeket a digitális térben azoknak az ügyfeleknek, akik számára az adott termék a viselkedési adatok alapján releváns lehet.

\section{Személyre szabott megoldások}

Az ügyfelek egyre inkább azt várják el, hogy számukra releváns terméket a megfelelő időpontban, nekik elfogadható árazással kínáljunk. Technológiailag mindez lehetséges, az Amodo mellett az Earnix jó példa erre. Ők az adatelemzés, modellezés és gépi tanulás eszközeit felhasználva három dimenzió (idő, termék, ár) mentén szabják személyre az adott ügyfélnek kínált megoldást.

Ez a trend azt is jelenti, hogy a termékek sokkal rugalmasabbá fognak válni. Szakítani kell az előre jól meghatározott tartamokkal, és lehetővé kell tenni az ügyfelek számára, hogy bármikor kössenek és lemondjanak egy-egy biztosítást (on demand insurance). Ez a törekvés már Magyarországon is megjelenik, élet vonalon példa erre az NN protect.me terméke, vagyonbiztosítások közül pedig a Cherrisk havidíjas lakásbiztosítása (ami biztosításjogi szempontból is rendkívül innovatív megoldás).

\section{Kockázatelbírálás, kárrendezés}

A big data, az IOT, a gépi tanulás (machine learning) és a mesterséges intelligencia (AI) a kockázatelbírálás és a kárrendezés területein jelentős szerepet kapnak. A Tractable például néhány fénykép feltöltése után másodpercek alatt ad nekünk kárbecslést egy gépjármükárra.

\section{Újfajta kockázatok megjelenése}

Tanulságos átgondolni, hogy pusztán a gépjármü-biztosítási szektorra milyen tényezők fognak hatást gyakorolni az elkövetkező években.

1. Az önvezető autók megjelenése már a kockázat viselőjének kérdését is felveti.

2. A connected cars megjelenése nem a nagyon távoli jövő, hiszen a 2018 óta gyártott minden autóban benne van a lehetősége a más eszközökkel való kommunikálásnak. Míg bizonyos kockázatokat ez csökkenteni tud, ezzel együtt újfajta kockázatok is meg kell, hogy jelenjenek a gépjármü-biztosításokban, ilyen például a cyber kockázat.

3. Az elektromos autókról általánosságban elmondható, hogy biztonságosabbak, ezeket nem lehet a hagyományos autókra kidolgozott modellekkel árazni.

4. Az autózás területén az egyetlen nem technológiához kapcsolódó trend az autóelőfizetések megjelenése és várható terjedése. Ezeken belül a biztosítás szinte kötelező elem kell, hogy legyen.

\section{Új versenytársak: a challenger biztosítók}

A „challenger” biztosítók azért jöttek létre, mert hisznek abban, hogy a ma rendelkezésre álló digitális eszközrendszer használatával jól tudják csinálni azt, amit az ügyfelek nem szeretnek a biztosításokban (ezek egy része látható az 1. ábrán). Erre jó példa az amerikai 
digitális egészségbiztosító, az Oscar megalapításának története. Ők ezt mondják magukról: „Nem azért alapítottuk a céget, mert imádjuk az egészégbiztosításokat. Igazából pont az ellenkezője miatt." Ezekre mutat példát a 3. ábrán látható négy plakát.

3. ábra: Oscar egészségbiztosítási hirdetések
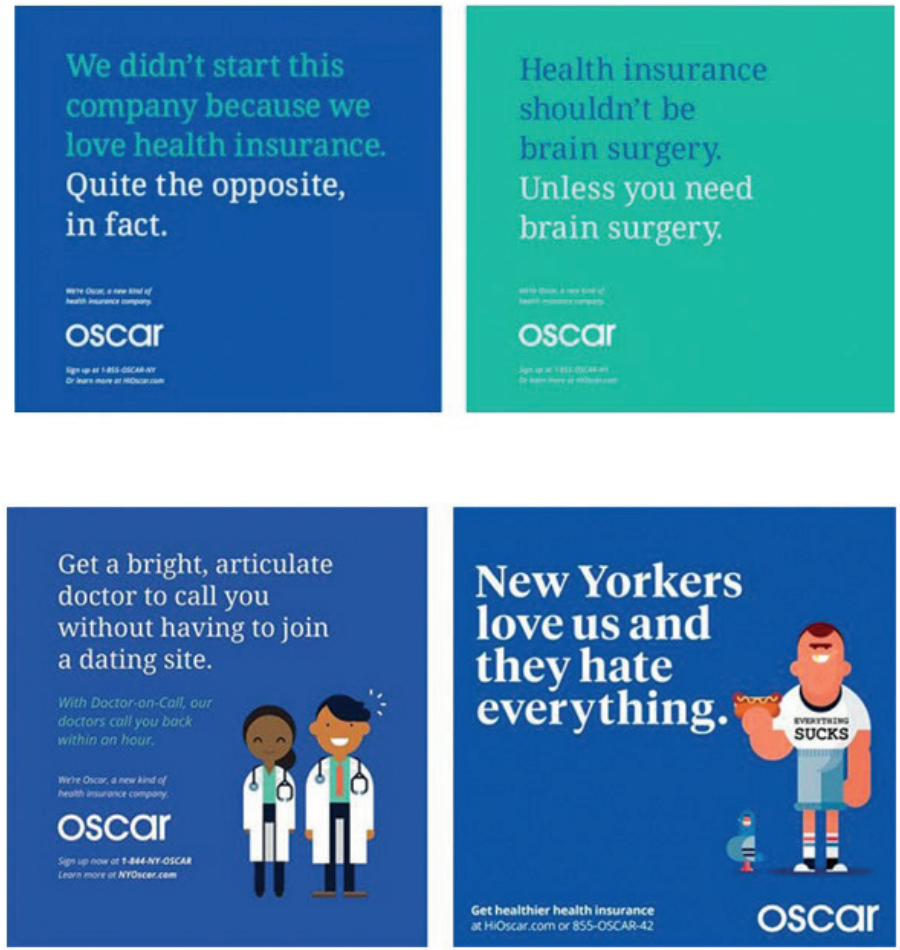

Forrás: Google

Ma már látjuk azt, hogy önmagában az operációs problémák megoldása nem elegendő ahhoz, hogy a kihívók (challengerek) fenntartható előnyt szerezzenek, és ezáltal komoly piaci hatást váltsanak ki. Azok tudnak igazán sikeresek lenni, akik a problémamegoldáson és az ügyfélélményen túl tényleg újfajta üzleti modellt építenek. Erre a legkézenfekvőbb példa a Lemonade, de Magyarországon a Cherrisk is ezek közé sorolható.

\section{Az értékesítés digitalizálódása}

A digitális alapra helyezett megoldások az értékesítés terén is újdonságot hoznak. A nem-életbiztosítási ágazatban ez tulajdonképpen már évek óta jelen van, de az életbiztosítási ág is ebbe az irányba hat. Ennek többféle megjelenését láthatjuk. Értékesítésben egyre inkább el kell tolódni az „eladunk” (push) irányból a „bevonzunk” (pull) irányba. Úgy is mondhatnám, hogy nem felkelteni kell az ügyfelek igényét a termékeink iránt, hanem meg kell találni azokat az ügyfeleket, akiknél éppen most jelenik meg egy-egy igény, számukra kell megoldást (és nem fedezetet) kínálni. Ez a fajta átalakulás a digitális térben mehet hatékonyan végbe. Ez egy hibrid értékesítési modellhez vezet, amelyben a digitális térben érjük el azokat az ügyfeleket, akik számára egy adott szolgáltatás releváns lehet. Meglátásom szerint az esetek többségében ennek befejezése ma még jellemzően személyes találkozón történik, de ebben is elmozdulás várható, hiszen ma már megvannak mind a jogszabályi, mind a technológiai feltételei annak, hogy személyes találkozó nélkül valósuljon meg a szerződéskötés. Erre a hibrid modellre már Magyarországon is látunk jó példákat, és nem csak az látható, hogy annál, aki ezt sikeresen végzi, hatékonyabb az ügyfélakvizíció, de (mivel ténylegesen meglévő ügyféligényre alapul az értékesítés) az állomány minőségi mutatói is jobbak. Mindez a toborzásra is hatással lehet, hiszen egy ilyen értékesítési modellben új szempontok mentén válogatott és felkészített biztosítási tanácsadók lehetnek sikeresek.

A hibrid értékesítésen túlmutatnak azok a megoldások, amelyek teljes mértékben digitalizálják a biztosítások értékesítését. Az amerikai Policygenius jó példa erre, ők az élet- és nem-életbiztosítások online értékesítését is végzik.

A veszélyközösség megszervezését is lehet digitális alapokra helyezni, ennek képviselője a Bought By Many, ők kisállat-biztosításokra specializálódtak.

\section{Backoffice automatizálása}

A backoffice folyamatok digitalizációjának legfőbb eredménye, hogy ezek gyorsulnak, hatékonyabbá és pontosabbá válnak, ami végső soron a megbízhatóságot növeli az ügyfelek és az értékesítők irányába is.

A biztosítók egyre inkább alkalmazzák a robotizált folyamatautomatizálást (Robotic Process Automation, RPA). Ez egyrészt jó technika a folyamatok hatékonyságának javítására, azok gyorsabbá és pontosabbá válnak. Ráadásul a biztosítói költségek csökkentésének is jó eszköze lehet, miközben az automatizálásnak köszönhetően a hibák száma csökken, ami compliance szempontból is javítja a biztosító teljesítményét (4. ábra). 


\section{4. ábra: A folyamatautomatizálás előnyei}

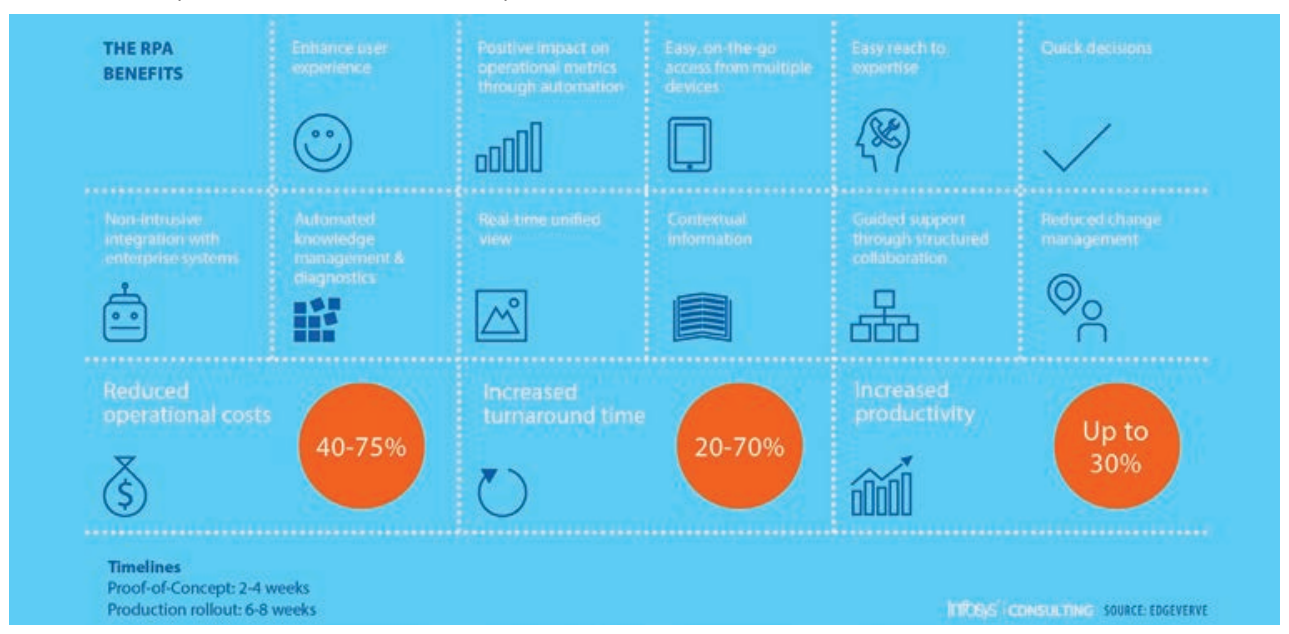

Forrás: https://www.infosysconsultinginsights.com/insights/robotic-process-automation/

\section{Az ökoszisztéma - több, mint biztositás}

A biztosítás jövője kapcsán az ökoszisztémában gondolkodás is egy gyakorta használt „buzzword”. Ugyanakkor egyértelműnek látom, hogy a biztosítási iparág ebbe az irányba fog elmozdulni, és egyre inkább abban kell gondolkodnunk, hogy fedezetek helyett szolgáltatásokat nyújtsunk ügyfeleinknek. A push-típusú értékesítés elmozdulása a pull felé azt is megköveteli, hogy azokon a platformokon legyünk aktívan jelen, ahol a (leendő) ügyfeleink életük egy-egy problémájára megoldást keresnek. Ezeken a helyeken pedig nem elsődleges termékként jelenik meg egy-egy biztosítási fedezet, hanem jellemzően addicionális szolgáltatásként. Jó példa erre a francia telekocsizó startup, a BlaBlaCar, akik az AXA-val közösen kifejlesztették a szolgáltatásukhoz illeszkedő gépjármű-biztosítást. Érdekessége ennek, hogy az AXA tulajdonképpen háttérszolgáltatóként van jelen, mind az értékesítési platform, mind a brand a BlaBla-hoz kötődik, a termék neve is BlaBlaSure. A gépjármü-biztosítási piacra az autógyártók is próbálnak belépni, a más területen is új sztenderdeket hozó Tesla például a biztosítást is maga nyújtja (Tesla Insurance).

A Bain\&Company kutatása szerint az ilyen megközelítés növeli az ügyfelek lojalitását, új ügyfeleket vonzhat, és ezek az ügyfelek kevésbé árérzékenyek (5. ábra).

\section{5. ábra: Az ökoszisztéma jövedelmet terme}

\section{How ecosystem services generate revenue for insurers}
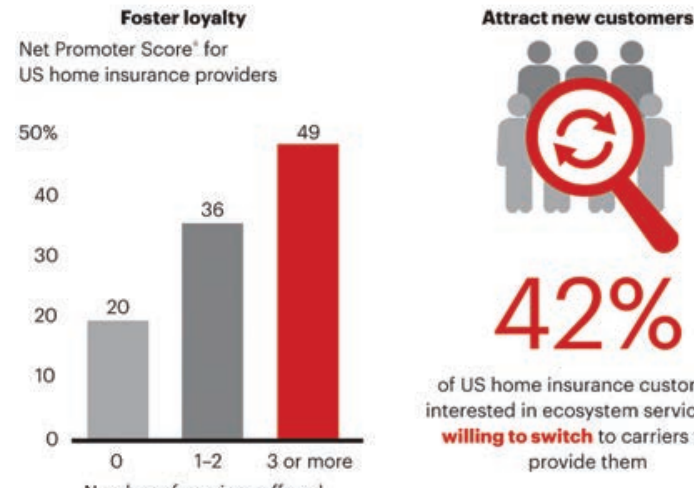

of US home insurance customers willing to switch to carriers that

provide them

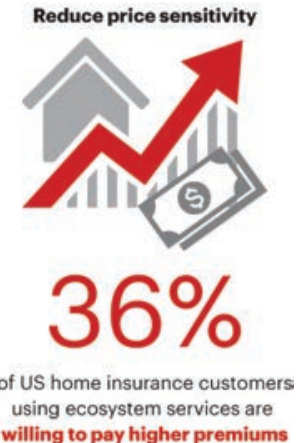

using ecosystem services are

Forrás: https://www.bain.com/insights/why-insurers-should-look-beyond-insurance-snap-chart/

Érzékelhető tehát már az a jelenség, hogy a szektorok határai elmosódnak. Ez nemcsak azzal jár, hogy a biztosítók új területeken jelennek meg mint szolgáltatók (pl. telekocsi platform a fenti példában), de azzal is, hogy új szereplők jelennek meg a biztosítási piacon.

Ahogy korábban már írtam, a digitalizáció megváltoztatja a fogyasztók viselkedését, és ez az iparágban is változást kényszerít ki. Az ilyen jellegű iparági szintű változások gyakran járnak meglévő szereplők kilépésével a piacról és új szereplők megjelenésével. Az autógyártókon túl ilyen lehet a technológiai óriások megjelenése, akik láthatóan megérkeztek az otthonunkba (pl. Amazon Alexa) és az egészség területére (pl. Apple Watch EKG).

Talán az egészségbiztosítás területe az, ahol a biztosítók már aktívan alkalmazzák azt a szemléletet, hogy fedezet helyett szolgáltatást kínáljanak ügyfeleiknek, és nem pusztán kockázataik kezeléséről gondoskodnak, de egészségmenedzserekké válnak. Látható, hogy az egészséggel, aktivitással kapcsolatos adatgyüjtés fontos az - egyébként adattal nem jól ellátott - biztosítók számára, illetve az is, hogy az ügyfelek értékelik a folyamatos jelenlétet és kapcsolatot a biztosítóval (pl. Generali Vitality)

Lépjünk ki az értékláncból!

A biztosítási iparágra jellemző, hogy az értéklánc minden elemét saját maga látja el. Meglátásom szerint ugyanakkor erre a megváltozott környezetben nem lesz képes. Partnerségre kell lépnie olyan szereplőkkel, akik az értéklánc egy-egy apró szegletében sokkal jobb megoldásokra képesek. Ezek a szereplők már jelen vannak, és új sztenderdeket állítanak fel.

Partnerség és együttmüködés kell, hogy a kulcsszavak legyenek a jövőben, és nyílt innovációban kell gondolkodni, aminek keretében az ügyfelek szolgálatába lehet állítani olyan tudást is, ami biztosítón belül nem elérhető. Természetesen gondolok itt insurtech 
vállalatokra, akikkel értelemszerüen partnerségre lehet lépni. Emellett érdemes talán megfontolni bizonyos területeken néhány versenytárssal való együttműködést (tipikusan közepes méretű szereplőknek, akiknél a mérethatékonyság egy Magyarország méretű piacon csak így érhető el).

\section{FINSURTECH}

Az ökoszisztémában gondolkodás és a potenciális partnerek keresése arra kell, hogy ösztönözze a biztosítókat, hogy szélesítsék látókörüket, és felismerjék, hogy minden cég, amely javítja az értékajánlatukat, érdekes partner lehet számukra.

Számomra meglepő például, hogy bár számos fintech megoldás jól alkalmazható lenne a biztosításban is, erre kevés példát látunk. Miért ne lehetne például robottanácsadót alkalmazni unit-linked élet- vagy nyugdíjbiztosításhoz?

Szintén érdemes gondolkodni a PSD2 szabályozásban rejlő lehetőségekben. Akár számlainformációs (AISP) vagy fizetési-kezdeményezési (PISP) szolgáltatóként, akár ilyen szolgáltatókkal való együttműködés által.

\section{Jó célok szolgálatában}

Roger Peverelli és Reggy de Feniks az insurtech négy hullámáról beszélnek. Az ő meglátásuk szerint már útban van a negyedik hullám, amely arról szól, hogy az új technológiák arra is lehetőséget adnak a biztosítóknak, hogy növeljék a társadalmi és gazdasági hatásukat.

Ilyen lehetne, ha a befektetési életbiztosítások területén hangsúlyt helyezünk a társadalom- és környezettudatos befektetésekre. Erre egy példa az egyik legígéretesebb magyar fintech, a Blueopes, akik a robottanácsadást kombinálják társadalom- és környezettudatos befektetéssel. Mind a robottanácsadás, mind az ESG (Environmental, social and governance) befektetés igazán releváns gondolat lehet például nyugdíjbiztosítások esetében. A robottanácsadásnak köszönhetően személyre szabható és megfelelő időközönként újra súlyozható az ügyfél portfóliója (ami ilyen távon szabályozói elvárás is). Az ESG pedig - amellett, hogy számos tanulmány kimutatta, hogy nem jár hozamáldozattal ez a típusú befektetés - azt az üzenetet is hordozza, hogy fektess olyan jövőbe, amilyenben nyugdíjasként élni szeretnél.

A mikrobiztosítások megjelenése is rendkívül jó hatással jár. Erre jó példa a BIMA. A BIMA célja nemcsak az, hogy felkavarja a biztosítási piacot, de elő kívánja segíteni azt is, hogy a pénzügyi szolgáltatások széles rétegek számára legyenek elérhetők. A BIMA-nak ma már 25 millió ügyfele van, akiknek 90 százaléka napi 10 dollárnál kevesebből él (6. ábra).

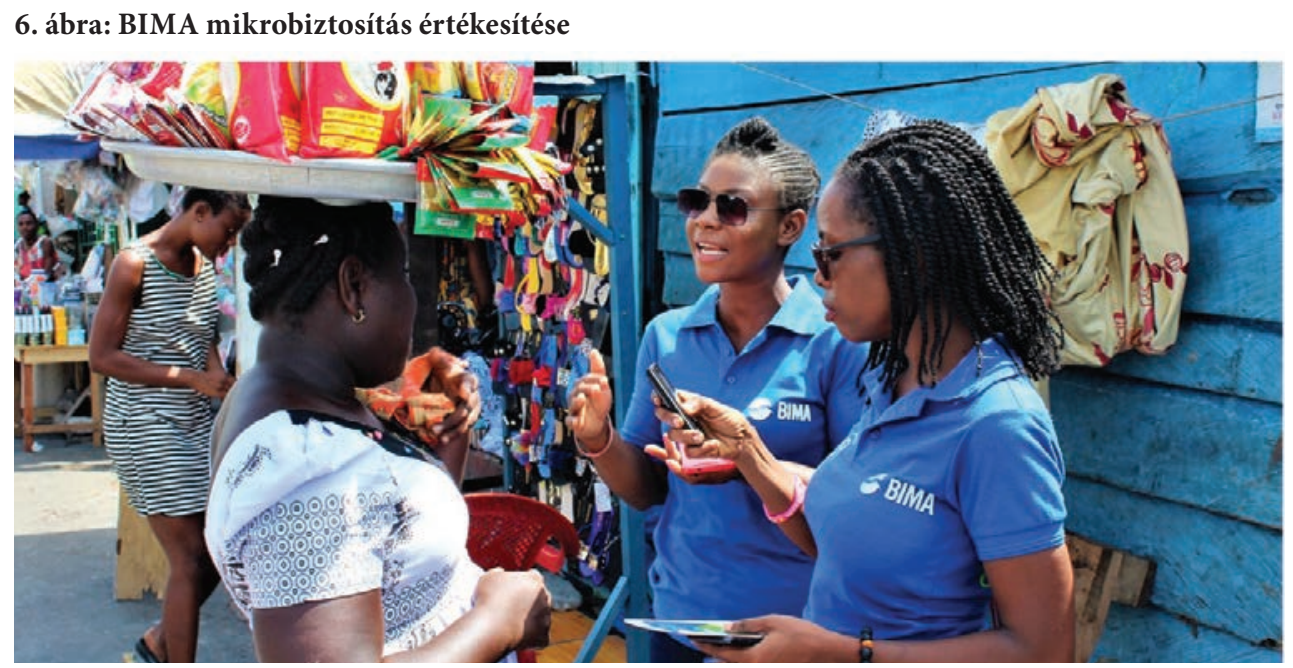

Forrás: http://www.bimamobile.com/

Az én meggyőződésem szerint, amikor innovációról beszélünk, a saját szervezetünk és iparágunk sikerén túl egy igazságosabb és fenntartható közös jövőért is dolgoznunk kell.

\section{IRODALOMJEGYZÉK}

Flavours of Fintech in Insurance by Roger Peverelli and Reggy de Feniks com/blog/zurich-insurance-group-incorporates-rpa-to-achieve-1b-of-savings/ (2019) Letöltés ideje: 2019-11-15.

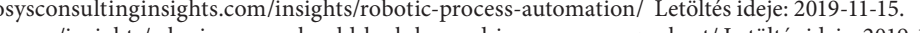

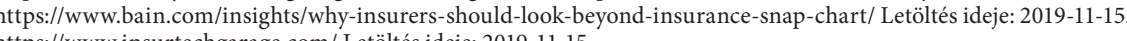

